\title{
The presence of home-cage stimuli attenuates spontaneous-alternation deficits in rats with septal lesions
}

\author{
GREGORY J. SMITH, CHARLES R. GOODLETT, RICHARD G. BURRIGHT \\ PETER J. DONOVICK, and NORMAN E. SPEAR \\ State University of New York, Binghamton, New York
}

\begin{abstract}
The present experiment examined the effects of the olfactory context on spontaneousalternation performance of young adult, female rats following septal lesions. Separate groups of rats were given either septal lesions $(n=24)$ or control surgery $(n=24)$, and then tested on the 8th postoperative day for spontaneous alternation across three trials. Half of the rats in each surgical group were tested in the presence of home-cage nest shavings located in a tray beneath the apparatus; the other septal and control groups were tested over clean, unsoiled wood shavings. Rats tested in the novel, clean-shavings environment showed the typical perserverative deficits in spontaneous alternation associated with septal lesions. Rats with septal lesions tested in the presence of the familiar olfactory stimuli from the home-litter shavings alternated at rates similar to those of controls. The training context had no effect on the alternation performance of controls. These results were interpreted as indicating that rats with septal lesions are differentially responsive to sensory conditions. In particular, the familiar olfactory stimuli may be especially potent in reducing the "hyperreactivity" resulting from the altered sensory processing following septal lesions. Differential salience of olfactory stimuli following such lesions may be related to reports of shifts in social behavior following disruption of septal functioning.
\end{abstract}

Previous work has indicated clearly that contextual and motivational cues present at the time of testing can modify the behavioral deficits typically associated with septal lesions. For example, the perseverative tendencies associated with septal lesions during extinction of a barpressing response (Fallon \& Donovick, 1970) or spatial reversal performance (Goodlett, Donovick, \& Burright, in press) can be attenuated with motivational shifts at the time of testing. Similarly, following septal lesions, deficits in performance of such tasks as passive avoidance depend on a number of factors, including the type of punishing stimulus employed (Frank \& Beatty, 1974; Gittelson, Donovick, \& Burright, 1969), environmental cuing of the task (Bengelloun, Burright, \& Donovick, 1977; Ellen \& Butter, 1969), and the temporal parameters of testing (Bengelloun, Burright, \& Donovick, 1976). The impact of septal lesions may,

This research was supported in part by grants from the National Science Foundation (BNS 78-02360) and National Institute of Mental Health (1 R01 MH 35219-01;02) to N.E.S. and a grant from the National Science Foundation (DAR7911233) to P.J.D. and R.G.B. The assistance of Norman Richter, Tim Wigal, Daniel Reinstein, and Steven Earley is gratefully acknowledged. The authors were affiliated with the Department of Psychology and the Center for Neurobehavioral Sciences of SUNY-Binghamton when this research was done. Requests for reprints should be addressed to Gregory J. Smith, Department of Psychology, Mather Memorial Building, Case Western Reserve University, Cleveland, Ohio 44106. indeed, be described as an alteration in multisensory integration (Donovick, Burright, \& Bengelloun, 1979) or attention (Gomer \& Goldstein, 1974). As such, the specific set of environmental stimuli available to the animal at the time of testing may, and frequently does, differentially affect the lesioned and intact animal.

Not surprisingly, then, the specific set of stimuli available during testing can determine the expression of perseverative deficits associated with septal lesions in spontaneous alternation tasks. When nondeprived rats were allowed successive trials in a homogeneous T-maze, intact animals typically alternated turns above chance (Dember \& Fowler, 1958), whereas rats with large septal lesions (Douglas \& Raphelson, 1966) or medial septal lesions failed to exhibit reliable alternation patterns. However, if the arms had distinct visual or olfactory cues, rats with septal lesions returned to the previously visited stimulus, even if that meant alternating the specific turning response (Clody \& Carlton, 1969; Dalland, 1970; Thomas, 1972). Thus, the type of perseverative deficits following septal lesions depends on what cues are available to direct behavior. Given the general hyperreactivity to enviromental stimulation following septal lesions (e.g., Donovick et al., 1979), differences in testing situations often alter the behavioral pattern of septals more dramatically than they do that of controls.

The specific approach used in the present investigation grew out of work, with intact infant rats, that 
had indicated that the testing context had an especially pronounced effect on learning and performance in developing rats (Spear, 1979). Training neonatal or infant rats in a contextual environment that resembled the home-nest environment (e.g., in the presence of littermates, litter shavings from the nest, or an anesthetized dam) facilitated performance on several learning paradigms (Smith \& Spear, 1978, 1980, 1981; Smith \& Bogomolny, 1983). In particular, 16-day-old rats, which normally perseverate during spontaneous-alternation tests, exhibit alternation performance more like that of intact adults when tested in the presence of litter shavings from the home nest (Smith \& Spear, 1978). Other investigators have suggested a parallel between the behavior of brain-damaged adults and that of developing animals (Teitelbaum, 1971; Teitelbaum, Wolgin, De Ryck, \& Marin, 1976; Nance, Phelps, Shryne, \& Gorski, 1977). This suggests that adult rats with septal damage may respond to manipulations of the testing context in a manner analogous to that of intact infant rats. The present investigation therefore examined the impact of the familiar olfactory cues of home litter on the spontaneous-alternation performance of adult rats given either septal lesions or control surgery. Given that septal lesions in adult rodents enhance social contact and cohesiveness among familiar conspecifics (Booth, Meyer, \& Abrams, 1979; Jonason \& Enloe, 1971), it was reasonable to assume that (1) the presence of olfactory cues from familiar animals might be an especially "salient" contextual condition for rats with septal lesions, and that (2) such stimuli might differentially affect exploratory behavior in a T-maze spontaneous-alternation task.

\section{METHOD}

\section{Subjects}

The subjects were 48 female Sprague-Dawley rats born and reared in the State University of New York at Binghamton colony. From weaning until 2 days before surgery (approximately 60 days of age), the rats were group housed in double wire cages with 8-10 same-sexed rats. Two days before surgery, the rats were transferred to standard laboratory polypropylene cages $(47.5 \times$ $26 \times 15 \mathrm{~cm}$ ), where they were housed in groups of four rats per cage. Fresh pine shavings, which were present when the rats were initially housed, were not changed until after testing ( 9 days later). The rats were maintained with ad-lib food and water in a climate-controlled vivarium on a 0700 (lights on)/2300 (lights off) cycle.

\section{Surgery}

Surgical procedures were conducted under aseptic conditions with the rats anesthetized by using Nembutal $(40 \mathrm{mg} / \mathrm{kg})$ supplemented locally by Xylocaine; all rats received intramuscular injections of atropine sulfate $(4 \mathrm{mg} / \mathrm{kg})$ as well. For each cage of four rats, two were assigned randomly to receive septal lesions and two underwent control surgical procedures. The rats were anesthetized and placed in a Kopf stereotaxic instrument that utilized a nose clamp to maintain the skull in the horizontal plane. The dura was exposed via small burr holes in the cranium. The coordinates for the electrode placement were $1.1 \mathrm{~mm}$ anterior and $0.9 \mathrm{~mm}$ lateral to bregma, and $4.5 \mathrm{~mm}$ ventral to the dura, with the electrode directed toward the midline at an angle of $10 \mathrm{deg}$. Septal lesions were produced by passing a $1.7-\mathrm{mA}$ direct current through the uninsulated tip $(0.5 \mathrm{~mm})$ of a No. 00 stainless steel insect pin to a large rectal cathode. Operated control rats underwent the same procedure, but the electrode was not lowered. Upon completion of the testing, the lesioned subjects were deeply anesthetized and perfused intracardially with $0.9 \%$ saline followed by $10 \%$ Formalin. Frozen coronal sections were taken through the lesion area at 80 microns, and stained with a metachromatic counterstain for cell bodies and fiber tracts (Donovick, 1974). The extent of lesion was determined using the atlas of König and Klippel (1963).

\section{Experimental Procedure}

A $2 \times 2$ completely randomized factorial design was used; it consisted of 2 surgery conditions (septal lesions or control surgery) crossed with 2 training contexts (9-day-old nest shavings taken immediately before testing from the rat's home cage or unsoiled, clean wood shavings). Surgery was performed 2 days after group housing, and spontaneous alternation was tested on the 8th postoperative day. On Days 2-7 postsurgery, all rats were handled for 2 min daily by an experimenter not involved in the behavioral testing. The lesioned rats displayed the typical septal rage syndrome early in the handling period, but the reaction had abated by the test day in most lesioned rats. On the test day, group assignments were made, with all four rats from each cage (two septals, two controls) assigned to the same shavings condition. The data are based on 48 female rats, with 12 rats in each of the four groups.

On the 8th postoperative day, each rat was given three trials in a T-maze constructed of clear Plexiglas. The startbox was $36 \mathrm{~cm}$ long $\times 11 \mathrm{~cm}$ wide $\times 12 \mathrm{~cm}$ high; each arm was $39 \mathrm{~cm}$ long $\times 16 \mathrm{~cm}$ wide $\times 12 \mathrm{~cm}$ high. Stainless steel trays were placed beneath the entire apparatus, $8 \mathrm{~cm}$ below the spaced, steel rods that formed the floor of the maze. These trays contained either nest shavings taken just before testing from the group's home cage or clean, unsoiled pine shavings from the colony supply. On each trial, a rat was placed in the startbox of the maze, and $3 \mathrm{sec}$ later the guillotine door separating the startbox form the choice point was raised and the latency timer simultaneously started. Each rat was given unrestricted access to the maze for $180 \mathrm{sec}$ or until it entered one of the two arms of the maze. After entering an arm of the maze, the guillotine door separating the arm from the choice point was lowered to prevent retracing, and the rat remained in the arm for $10 \mathrm{sec}$. The rat was then removed from the arm and placed in a holding cage during the 30-sec intertrial interval. Since each rat was given three choice trials on the test day, each had two chances to alternate the side entered, that is, from Trial 1 to Trial 2 and from Trial 2 to Trial 3. The dependent variable reflecting choice behavior was defined as the probability of alternation, with each animal showing $0 \%$ alternation (never changed turning response), $50 \%$ alternation (switched responses on one of the two opportunities), or $100 \%$ alternation (switched responses on both opportunities). Latencies to complete each trial were also analyzed.

\section{RESULTS}

\section{Histology}

The surgical procedures used here in general produced large, bilateral lesions of the entire precommissural septum; reconstructions of a smallest, a typical, and a large septal lesion are shown in Figure 1. The lesions always destroyed the anterior medial septum and invaded the diagonal band of Broca; some unilateral sparing of the lateral nuclei was found occasionally. Extraseptal damage included invasion of the corpus callosum for most of 

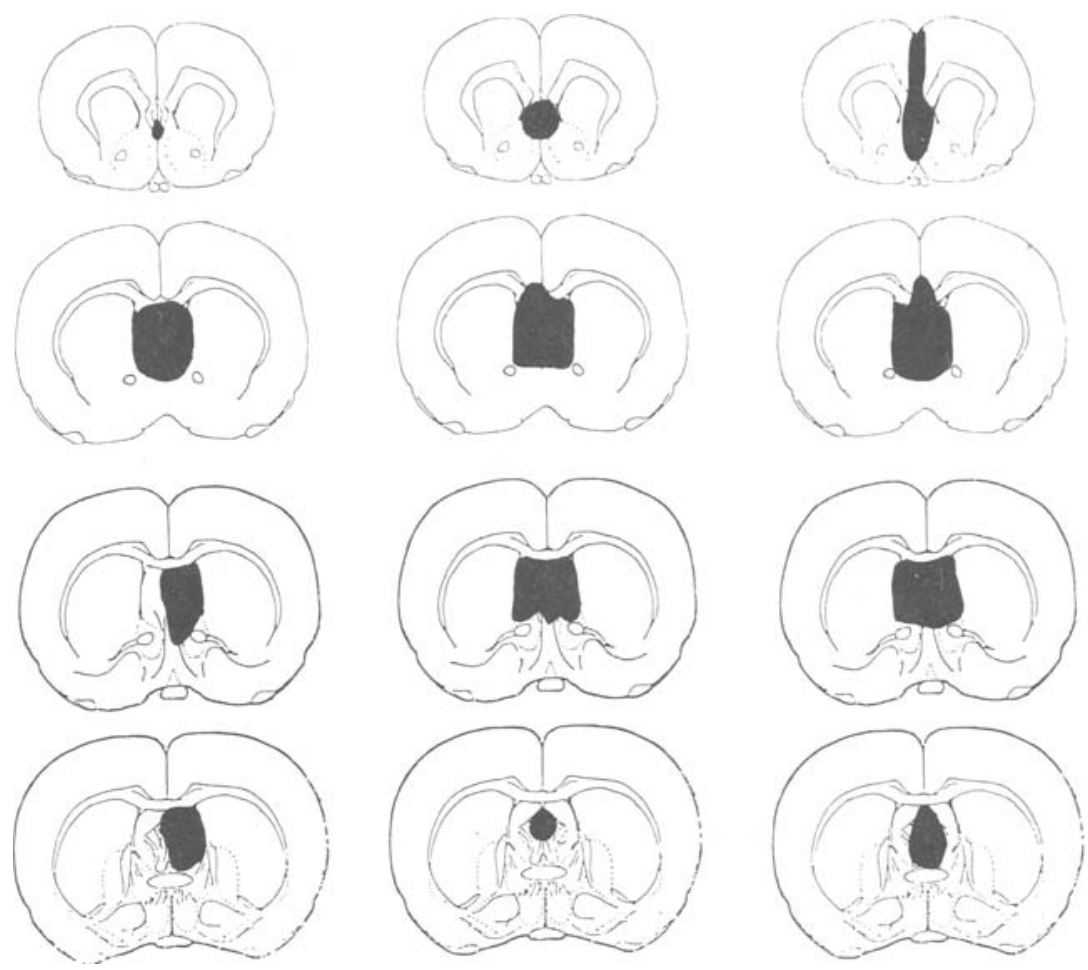

Figure 1. Representative sections from König and Klippel (1963) of the extent of septal damage form a small (left column), a typical (middle column), and a large (right column) septal lesion. The four sections are taken from anterior (top) to posterior (bottom) through the septal area.

the rats (especially near the electrode track), accompanied by damage to ventral areas of the medial cortex overlying the corpus callosum. The caudate and anterior commissure generally were spared, and the nucleus accumbens and the area ventral to the anterior septum incurred only small amounts of damage. As is often found with large septal lesions, no correlation between extent of damage and the behavioral results could be discerned.

\section{Spontaneous Alternation}

The results of the spontaneous alternation tests, in terms of the mean probability of alternation across the three trials, are shown in Figure 2. The operated control rats chose alternate arms on $60 \%$ of their opportunities after their first trial. While this level of alternation was slightly lower than expected, it is not at variance with alternation behavior typically found for intact, adult rats (Dember \& Fowler, 1958; Smith $\&$ Spear, 1978). As seen in Figure 2, the alternation rate of controls was not markedly influenced by the training context (i.e., home litter shavings vs. clean shavings under the apparatus). In contrast, the performance of rats with septal lesions was dramatically affected by the type of shavings beneath the apparatus. The group of rats with septal lesions tested

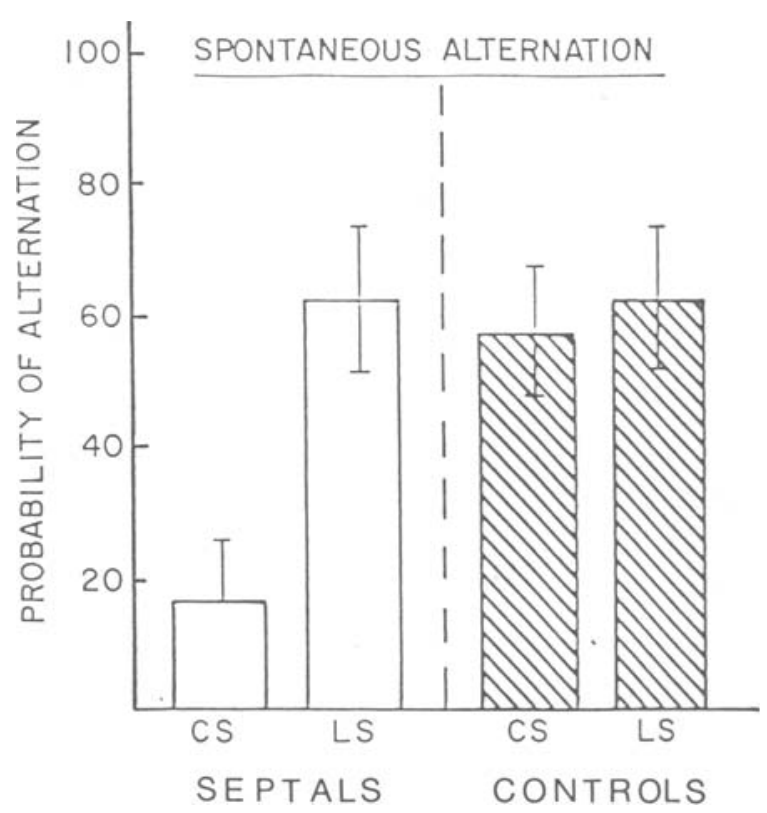

Figure 2. Probability of selecting the alternative maze arm averaged across the three test trials (two alternation opportunities). CS, the training context was clean, unsoiled shavings; LS, the training context was home litter shavings. 
in the presence of clean shavings clearly perseverated their choices; they responded to alternate arms on only $17 \%$ of all test trials. This perseverative deficit in spontaneous alternation in the clean-shavings condition resembled that of similarly lesioned rats observed in other laboratories (Clody \& Carlton, 1969; Douglas \& Raphelson, 1966; Numan, 1978). However, rats with septal lesions tested in the presence of familiar home nest shavings demonstrated alternation performance equal to the operated-control group. Although the large septal lesions of the rats tested over home shavings were not observably different from the lesions of those tested over clean shavings, the septals tested over home shavings reached a $63 \%$ alternation rate across the three test trials.

A $2 \times 2$ analysis of variance of alternation performance indicated a significant lesion $\times$ training context interaction $[F(1,44)=5.79, p<.025]$, as described above. Additional, specific comparisons indicated that, while rats with septal lesions tested over home-litter shavings failed to differ from operated controls $(F<1.0)$, the septal group tested over clean shavings alternated reliably less than their control counterparts $[\mathrm{F}(1,44)=4.11, \mathrm{p}<.05]$. The alternation performance of operated control rats was not affected by the training context $(\mathrm{F}<1)$.

Analysis of latency scores indicated that, regardless of their training context, rats with septal lesions required considerably more time to reach the goalbox $(X=53.5$ sec; $S E M=5.5)$ than did controls $[X=$ 16.9; $\mathrm{SEM}=5.1 ; \mathrm{F}(1,44)=22.8, \mathrm{p}<.001]$. Although the increased latencies do not agree with previous reports of faster performance of rats with septal lesions, compared with intact subjects (Donovick, 1968; Douglas \& Raphelson, 1966), they are consistent with several reports of decreased activity of septals in a novel open field (e.g., Corman, Meyer, \& Meyer, 1967). It was noted in the present study that the septals tended to "freeze" in the startbox at the outset of each trial before leaving to select a maze arm. Neither the main effect of training context nor its interaction with surgery treatment attained statistical significance on the latency measure.

\section{DISCUSSION}

The present experiment with adult female rats supports the contention that lesion-induced performance deficits are situationally specific (Bengelloun et al., 1976; Donovick et al., 1979; Goodlett et al., in press). In this case, the presence of familiar olfactory cues in the testing environment eliminated spontaneous alternation deficits associated with septal lesions. Specifically, female rats tested in the presence of olfactory stimuli from their home environment (which included stimuli of conspecifics), alternated choices at a rate similar to that of controls. In con- trast, rats with lesions tested in a novel context (without familiar home odors) exhibited response perseveration.

That the presence of home-nest shavings beneath the training apparatus affected the alternation performance of mature rats with septal lesions, but not intact controls, again suggests that the lesioned rats are differentially affected by their sensory world. The extent of this effect was limited to alternation, and did not include temporal parameters of responding. Interestingly, the response pattern of these braindamaged adult rats resembles that of immature preweanlings. For instance, Smith and Spear (1978) found that 16-day-old intact rats selected the same maze arm in a spontaneous alternation paradigm when tested in a "novel" olfactory environment. However, this tendency was eliminated in developing rats, as it was in our mature rats with septal lesions, when the testing was conducted in the presence of olfactory stimuli from the home nest. While the sensory world of a developing rat undoubtedly differs from that of an adult (with or without a septal lesion), the parallel behavioral effects of a familiar context are intriguing. These findings are consistent with the Teitelbaum's (1971) suggestion that some of the patterns of recovery of function after brain damage may parallel, or even show some dynamic commonality to, behavioral development.

Previously, we suggested that one effect of septal lesions is to alter the way in which the animal attends to various environmental cues (Bengelloun et al., 1976, 1977; Donovick, et al., 1979; Donovick, Burright, \& Fink, 1978; Goodlett et al., in press). Thus, the septal area may be considered as part of a "comparator" complex which integrates need state, past experience, and present environmental cues; damage to the septal region alters the manner in which the organism assimilates information. Our data suggest that relative to intact animals, those with septal lesions are more apt to focus quickly and persistently on one aspect of their environment (e.g., Donovick et al., 1978), and are less capable of integrating a large number of competing stimuli and/or consequences of their behavior than intact controls. When recognition and integration of new information is required, the lesioned animal appears to focus on a limited number of "highly salient" cues, with a resultant behavioral or attentional rigidity.

Exposure to novel environments are commonly assumed to elicit a fear response with an associated hormonal release that can alter information processing (e.g., Isaacson, Dunn, Rees, \& Waldock, 1976; Sandman, Miller, Kastin, \& Schally, 1972). Animals with septal lesions show an enhanced reactivity to novel or stressful situations, including an exaggerated hormonal response (Brick, Burright, \& Donovick, 1979; Corman et al., 1967; Dobrakovova, Kvetnansky, Torda, \& Murgas, 1982; Donovick \& Wakeman, 
1969; Seggie \& Brown, 1976), perhaps contributing to behavioral differences. In novel situations, the behavior of animals with septal lesions apparently becomes controlled by a limited number of highly salient stimuli (e.g., Dalland, 1970, 1974; Gomer \& Goldstein, 1974; Thomas, 1972), with a consequent behavioral rigidity. However, behavioral inflexibility can be diminished by explicit and dramatic changes in contextual cues, as with motivational changes (Fallon \& Donovick, 1970; Goodlett et al., in press), or by presentation of additional, explicit environmental cues (Bengelloun et al., 1977; Ellen \& Butter, 1969). The present investigation indicates that behavioral rigidity of septals in exploring a novel maze may also be reduced by ambient, familiar nest odors.

Over the last 15 years, there has been a growing body of literature which suggests that septal lesions alter several aspects of social behavior (e.g., Albert \& Chew, 1980; Meyer, Ruth, \& Lavonde, 1978). The increased emotionality and "rage" typically associated with septal damage (e.g., Goodlett, Engellenner, Burright, \& Donovick, 1982; Slotnick, McMullen, \& Fleischer, 1973) may, at times, be translated into increased aggression (cf. Albert \& Chew, 1980; Donovick \& Burright, 1982). However, both rats (Jonason \& Enloe, 1971; Poplawsky \& Johnson, 1973) and mice (Booth et al., 1979) with septal lesions show increased nonaggressive social contact when tested with familiar conspecifics. Perhaps such changes in social cohesiveness, induced by septal lesions, result from changes in the salience of stimuli related to social behavior (Meyer et al., 1978). From this perspective, the elimination of the alternation deficits of rats with septal lesions by familiar, conspecific olfactory stimuli may have resulted from the lesion-induced changes in a "social comfort motive." Thus, the familiar olfactory cues containing information from cagemates may be like being with a familiar conspecific, perhaps reducing the hyperreactive, hyperemotional response of rats with septal lesions. The presence of such information may increase the potential flexibility of animals with septal lesions by reducing their emotional reactivity, thereby allowing exploratory patterns more typical of normal animals. Interestingly, the olfactory cues did not "normalize" all aspects of the behavior of the lesioned rats. That is, while the alternation pattern of rats with septal lesions was affected by such stimuli, the elevated latency to respond was not altered. Nonetheless, these data provide important information concerning the differential impact (and, by inference, the salience) of a familiar olfactory context for rats with septal damage relative to intact controls.

\section{REFERENCES}

Albert, D. J., \& Chew, G. L. The septal forebrain and the inhibitory modulation of attack and defense in the rat. $A$ review. Behavioral \& Neural Biology, 1980, 30, 357-388.
Bengelloun, W. A., Burright, R. G., \& Donovick, P. J. Nutritional experience and spacing of shock opportunities alter the effects of septal lesions on passive avoidance acquisition by male rats. Physiology \& Behavior, 1976, 16, 583-587.

Bengelloun, W. A., Burright, R. G., \& Donovick, P. J. Septal lesions, cue availability, and passive avoidance acquisition by hooded male rats of two ages. Physiology \& Behavior, 1977, 18, 1033-1037.

Booth, C. L., Meyer, P. M., \& Abrams, J. Changes in social behavior of mice with septal lesions. Physiology \& Behavior, 1979, 22, 931-937.

Brick, J., Burright, R. G., \& Donovick, P. J. Stress responses of rats with septal lesions. Pharmacology, Biochemistry \& Behavior, 1979, 11, 693-700.

Clody, D. E., \& Carlton, P. L. Behavioral effects of lesions of the medial septum of rats. Journal of Comparative and Physiological Psychology, 1969, 67, 344-351.

Corman, C. D., Meyer, P. M., \& Meyer, D. R. Open-field activity and exploration in rats with septal and amygdaloid lesions. Brain Research, 1967, 5, 469-476.

DALland, T. Response and stimulus perseveration in rats with septal and dorsal hippocampal lesions. Journal of Comparative and Physiological Psychology, 1970, 71, 114-118.

Dalland, T. Stimulus perseveration of rats with septal lesions. Physiology \& Behavior, 1974, 12, 1057-1061.

Dember, W. N., \& Fowler, H. Spontaneous alternation behavior. Psychological Bulletin, 1958, 66, 569-578.

Dobrakovova, M., Kvetnansky, R., Torda, T., \& Murgas, $K$. Changes of plasma and adrenal catecholamines and corticosterone in stressed rats with septal lesions. Physiology \& Behavior, 1982, 29, 41-45.

Donovick, P. J. Effects of localized septal lesions on hippocampal EEG activity and behavior in rats. Journal of Comparative and Physiological Psychology, 1968, 66, 569-578.

Donovick, P. J. A metachromatic stain for neural tissue. Stain Technology, 1974, 49, 49-51.

Donovick, P. J., \& Burright, R. G. Genetic influences on responses to brain lesions. In I. Lieblich (Ed.), Genetics of the brain. Amsterdam: Elsevier/North Holland, 1982.

Donovick, P. J., Burright, R. G., \& Bengelloun, W. A. The septal region and behavior: An example of the importance of genetic and experiential factors in determining effects of brain damage. Neuroscience \& Biobehavioral Reviews, 1979, 3, 83-96.

Donovick, P. J., Burright, R. G., \& Fink, E. A. Discrimination behavior of rats with septal lesions in a cue additiondeletion paradigm. Physiology \& Behavior, 1978, 22, 123-131.

Donovick, P. J., \& W AKeman, K. A. Open-field luminance and "septal hypermotionality." Animal Behaviour, 1969, 17, 186-190.

Douglas, R. J., \& Raphelson, A. C. Spontaneous alternation and septal lesions. Journal of Comparative and Physiological Psychology, 1966, 62, 320-322.

Ellen, P., \& ButTer, J. External cue control of DRL performance in rats with septal lesions. Physiology \& Behavior, 1969 , 4, 1-6.

Fallon, D., \& Donovick, P. J. Low resistance to extinction in rats with septal lesions under inappropriate appetitive motivation. Journal of Comparative and Physiological Psychology, $1970,73,150-156$.

Frank, L. H., \& Beatty, W. W. Effects of septal lesions on passive avoidance behavior using ice water as the aversive stimulus. Physiology \& Behavior, 1974, 12, 321-323.

Gittelson, T. L., Donovick, P. J., \& Burright, R. G. Facilitation of passive avoidance acquisition in rats with septal lesions. Psychonomic Science, 1969, 17, 292-297.

Gomer, F. E., \& Goldste in, R. Attentional rigidity during exploratory and simultaneous discrimination behavior in septal lesioned rats. Physiology \& Behavior, 1974, 12, 19-28.

Goodlett, C. R., Engellenner, W. J., Burright, R. G., \& Donovick, P. J. Influence of environmental rearing history and postsurgical environmental change on the septal rage syndrome in mice. Physiology \& Behavior, 1982, 28, 1077-1081. 
Goodlett, C. R., Donovick, P. J., \& Burright, R. G. Attenuation of reversal deficits of mice with septal lesions by shifts in the motivational context. Behavioral Neuroscience, in press.

Isaacson, R. L., Dunn, A. J., Rees, H., \& Waldock, B. ACTH 4-10 and improved use of information in rats. Physiological Psychology, 1976, 4, 159-162.

Jonason, K. R., \& Enloe, L. J. Alterations in social behavior following septal and amygdaloid lesions in the rat. Journal of Comparative and Physiological Psychology, 1971, 75, 286-301.

König, J. F. R., \& KLIPPEL, R. A. The rat brain. A stereotaxic atlas. Baltimore: Williams \& Wilkins, 1963.

Meyer, D. R., Ruth, R. A., \& Lavonde, D. G. The septal social cohesiveness effect: Its robustness and main determinants. Physiology \& Behavior, 1978, 21, 1027-1029.

Nance, D. M., Phelps, C., Shryne, J. E., \& Gorski, R. A. Alterations by estrogen and hypothyroidism in the effects of septal lesions on lordosis behavior of male rats. Brain Research Bulletin, 1977, 2, 49-53.

Poplawsky, A., \& Johnson, D. A. Open-field behavior of rats following lateral or medial septal lesions. Physiology \& Behavior, 1973, 11, 845-854.

Numan, R. Cortical-limbic mechanisms and response control: A theoretical review. Physiological Psychology, 1978, 6, 445-470.

Sandman, C. A., Miller, L. H., Kastin, A. J., \& Schally, A. Neuroendocrine influence on attention and memory. Journal of Comparative and Physiological Psychology, 1972, 80, 54-58.

SegGie, J., \& Brown, G. The effects of ablation of the septal nuclei in the rat on circadian variation and stress response pattern of corticosterone, growth hormone, and prolactin. In J. F. DeFrance (Ed.), The septal nuclei: Advances in behavioral biology (Vol. 20). New York: Plenum Press, 1976.

Slotnick, B. M., McMullen, M. F., \& Fleischer, S. Changes in emotionality following destruction of the septal area in albino mice. Brain, Behavior and Evolution, 1973, 8, 241-252.

Smith, G. J., \& Bogomolny, A. Appetitive instrumental training in preweanling rats: I. Motivational determinants. Developmental Psychobiology, 1983, 16, 119-128.

Smith, G. J., \& Spear, N. E. Effects of home environment on withholding behaviors and conditioning in infant and neonatal rats. Science, 1978, 202, 327-329.

Smith, G. J., \& Spear, N. E. Facilitation of conditioning in two-day-old rats by training in the presence of conspecifics. Behavioral and Neural Biology, 1980, 28, 491-495.

Smith, G. J., \& Spear, N. E. Home environmental stimuli facilitate learning of shock escape spatial discrimination in rats 7-11 days of age. Behavioral and Neural Biology, 1981, 31, 360-365.

SPEAR, N. E. Memory storage factors leading to infantile amnesia. In G. Bower (Ed.), The psychology of learning and motivation (Vol. 13). New York: Academic Press, 1979.

Teitelbaum, P. The encephalization of hunger. In E. Stellar \& J. M. Sprague (Eds.), Progress in physiological psychology (Vol. 4). New York: Academic Press, 1971.

Teitelbaum, P., Wolgin, D. L., De Ryck, M., \& Marin, O. S. Bandage-backfall reaction: Occurs in infancy, hypothalamic damage, and catalepsy. Proceedings of the National Academy of Sciences, U.S.A., 1976, 73, 3311-3314.

Tномаs, J. B. Stimulus perseveration and choice behavior in rats with septal lesions. Journal of Comparative and Physiological Psychology, 1972, 80, 97-105.

(Manuscript received August 12, 1982; revision accepted for publication April 10, 1983.) 